\title{
OPERATION OF THE NSF-ARIZONA ACCELERATOR FACILITY FOR RADIOISOTOPE ANALYSIS AND RESULTS FROM SELECTED COLLABORATIVE RESEARCH PROJECTS
}

\author{
T W LINICK, A J T JULL, L J TOOLIN, and D J DONAHUE \\ NSF-Arizona Accelerator Facility for Radioisotope Analysis, Department \\ of Physics, University of Arizona, Tucson, Arizona 85721 \\ ABSTRACT. Radiocarbon dating at the Arizona accelerator facility has improved substan- \\ tially in the last three years. Since starting to use graphite targets (see Jull et al, 1986), we have \\ been able to obtain routinely a precision of $\mathrm{ca} \pm 1 \%$ (ca $80 \mathrm{yr}$ ) for relatively modern material. \\ Our routine technique of tuning and operating the tandem accelerator mass spectrometer \\ (TAMS) and our method of calculating ${ }^{14} \mathrm{C}$ results are discussed in detail. Data on activity \\ ratios of oxalic acid-II/oxalic-I are presented. Examples of the wide variety of projects on \\ which we have collaborated are given. Brief discussions of three such projects are presented \\ for our colleagues who were unable to attend this conference: an Arizona Indian archaeologic \\ project, a study of megafaunal extinctions, and a study of the growth of phosphorite nodules \\ on the sea floor off the Peruvian coast.
}

\section{INTRODUCTION}

Since the installation of the NSF-Arizona Accelerator Facility for Radioisotope Analysis in 1981 and the first detection of ${ }^{14} \mathrm{C}$ and early test analyses in 1982 (Donahue et al, 1983), operation of this instrument for ${ }^{14} \mathrm{C}$ analyses has become routine. Over 500 sample measurements were made in each of 1983 and 1984; most of these measurements used iron carbide as the target material, and the precision obtainable with $\mathrm{Fe}-\mathrm{C}$ bead targets was ca 1.5 to $3 \%$. Since late 1984 , catalytically produced graphite (see Jull et al, 1986) has become our target material, providing average beam strengths nearly an order of magnitude higher than the average of those from Fe-C targets. Precisions of ca $1 \%$ for material $<5000$ years old are generally attainable with graphite targets. Nearly 400 samples were dated in just over four months in 1985 .

\section{OPERATION OF THE NSF-ARIZONA TAMS}

At the start of operation, the carbon targets are mounted in aluminum holders (see Jull et al, 1986), placed into a circular target wheel, which has a capacity of 10 targets, and inserted into the vacuum system. Typical vacuum levels in the source during operation are $8 \times 10^{-7}$ torr. After a $25 \mathrm{kV}$ bias is applied to the target plate and the Cs beam is focused on the $1 \mathrm{~mm}$ diameter target, each target is sequentially left in the Cs beam for five minutes to cesiate the target surface and to remove surface contamination.

A schematic diagram of the TAMS system is presented as Figure 1. In each target wheel, there are normally two targets made from standard material (usually, NBS oxalic acid I and II) in positions 1 and 6, and either 8 sample targets or 7 sample targets plus a target made from a material containing no ${ }^{14} \mathrm{C}$ before preparation. One target is chosen for tuning of the machine. First, the ${ }^{12} \mathrm{C}^{-}$beam is maximized at the $\mathrm{LEC}$ by adjustment of the Cs focusing controls, the Einzel (gridded) lens at the exit of the source, and the magnetic field provided by the injection magnet $\left(\mathrm{M}_{\text {inj }}\right)$. Next, the same focusing is done for the ${ }^{13} \mathrm{C}^{-}$beam by increasing the field of the injection magnet. At this point, the LEC is hydraulically moved out of the beam- 


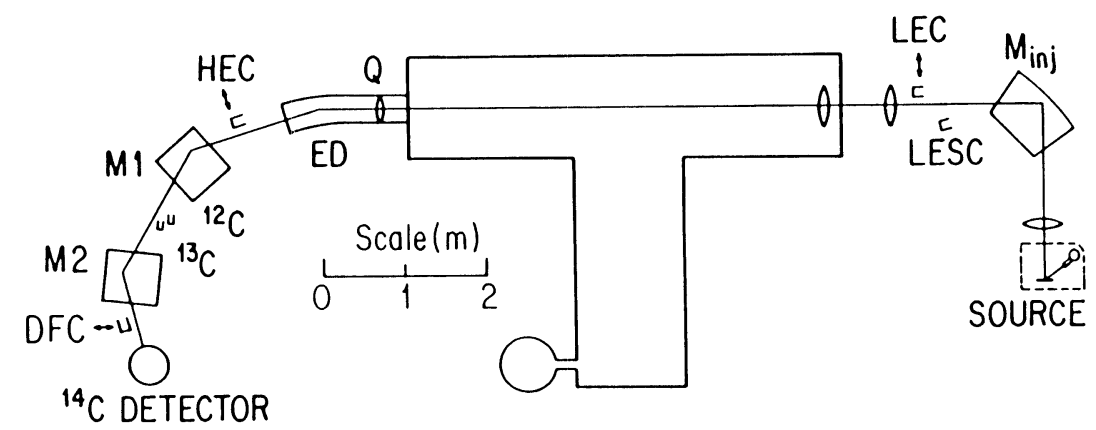

Fig 1. Schematic diagram of Arizona TAMS. Abbreviations used are $\mathbf{M}_{\text {inj }}$, injection magnet; I.EC, low-energy Faraday cup; I.FSC, low-energy Faraday side cup; $Q$, electrostatic quadrupole focus; E.1), electrostatic deflector; $\mathrm{Ml}$ and $\mathrm{M} 2$, high-energy magnets; ${ }^{12} \mathrm{C}$ and ${ }^{13} \mathrm{C}$, high-energy Faraday side cups for those isotopes; and DFC, detector Faraday cup.

line and the ion beam is allowed to pass through the accelerator, the terminal of which is at ca 1.8 million volts (MV); the beam passes through the argon gas "stripper canal" to strip electrons from the carbon and molecular carbon ions. The molecular ions are completely dissociated if the $3+$ charge state is selected; energy/charge selection is performed by the voltage applied to the electrostatic deflector at the exit of the tandem accelerator, at which point the $3+$ ions have ca $7.2 \mathrm{MeV}$ energy. With the electrostatic quadrupole focusing $(Q)$ and deflector (ED) fixed at their preselected values, the settings of the injection magnet, the Einzel lens, the stecrers at the low energy end of the accelerator, an additional combination of lenses at the entrance to the accelerator and the exact voltage applied to the terminal are adjusted iteratively to give the optimal ${ }^{13} \mathrm{C}^{3+}$ beam current at the high energy Faraday cup (HEC). Typically, the transmission, defined as the number of particles detected at the HEC divided by the number of particles detected at the LEC, is ca $20 \%$ with a terminal voltage of ca $1.8 \mathrm{MV}$, ca $15 \%$ with a terminal voltage of ca $1.5 \mathrm{MV}$. A detector Faraday cup (I)FC) is inserted into the beamline immediately before the ${ }^{14} \mathrm{C}$ detector. By hydraulic removal of the HEC from the beamline, the ion beam is allowed to pass through the high energy magnets (M1 and M2) to the IFC. By additional iterative adjustment of the fields of $\mathrm{M} 1$ and $\mathrm{M} 2$, of the terminal voltage, of the injection lenses, and the Einzel lens, the ${ }^{13} \mathrm{C}^{3+}$ current is optimized at the DFC; typical ${ }^{13} \mathrm{C}^{3+}$ transmission from the HEC to the DFC is ca $95 \%$. At this point, tuning of the instrument using the ${ }^{13} \mathrm{C}$ beam is complete, and the 3 magnets $\left(\mathrm{M}_{\mathrm{inj}}, \mathrm{M} 1\right.$, and $\left.\mathrm{M} 2\right)$ are scaled to pass the ${ }^{14} \mathrm{C}$ beam, $i e$, the field strengths of the 3 magnets are increased by the factor of the square root of $(14 / 13)$. At this point, with all Faraday cups removed from the beamline, the ${ }^{14} \mathrm{C}^{3+}$ beam should be optimally focused on the silicon surface-barrier detector. In order to measure a ${ }^{13} \mathrm{C}$ beam that passes through the accelerator, a voltage can be put on the injection magnet vacuum chamber ("bouncer") to slow the ${ }^{13} \mathrm{C}^{-}$ions so that they pass through $\mathrm{M}_{\mathrm{inj}}$ and into the accelerator; maximization of the ${ }^{13} \mathrm{C}^{3+}$ beam at the HEC is accomplished by adjustment of the bouncer voltage.

For ${ }^{14} \mathrm{C}$ measurements, the ${ }^{14} \mathrm{~N},{ }^{14} \mathrm{C},{ }^{13} \mathrm{C}$, and ${ }^{12} \mathrm{C}^{3+}$ ions, reaching the 
detector can be distinguished by measuring only the residual energy of the events if the detector chamber is filled with ca 7 torr of isobutane; the energy of the particles at the detector increases in the order the isotopes are given above; the peaks are well resolved, and a range of energy channels that contains only ${ }^{14} \mathrm{C}$ events can be selected and furnished to the DEC computer system used for operating the TAMS. By turning the bouncer on, with no further adjustment of any of the magnets, the ${ }^{13} \mathrm{C}^{3+}$ beam intensity is measured at the ${ }^{13} \mathrm{C}$ high-energy Faraday side cup, located between M1 and M2, using a current integrator typically set at $10^{-9}$ coulombs/pulse for measurement of graphite targets. In routine operation, we cycle between measuring ${ }^{13} \mathrm{C}$ for 10 seconds and ${ }^{14} \mathrm{C}$ for 50 seconds, with a 2 -second delay between the measurements. Each target is measured sequentially for 15 of these $10 / 50$-second cycles plus an extra ${ }^{13} \mathrm{C}$ cycle at the end before continuing to the next target; the ${ }^{13} \mathrm{C}$ values measured before and after each ${ }^{14} \mathrm{C}$ cycle are averaged to normalize properly the ${ }^{14} \mathrm{C} /{ }^{13} \mathrm{C}$ ratio measured for that cycle. Typically, we go around the target wheel 4 times, so that the total measurement time on each target is ca 1 hour. The DEC computer system largely controls the cycling of isotopes, accumulation of data, and calculation of results for each 15-minute run. At present, the target wheel is rotated manually.

\section{CALCULATION OF RESULTS}

The results are calculated by using the ${ }^{14} \mathrm{C} /{ }^{13} \mathrm{C}$ ratios of each sample and those of the standards. The measured ${ }^{14} \mathrm{C} /{ }^{13} \mathrm{C}$ ratio of the standard is adjusted by making a blank correction (see below), a multiplicative correction for the activity of the standard, relative to the correct AD 1950 standard value, and a correction for the $\delta^{13} \mathrm{C}$ value (measured on a conventional mass spectrometer) for graphite samples. The catalytically-produced graphite is homogenized before TAMS measurement of the ${ }^{14} \mathrm{C} /{ }^{13} \mathrm{C}$ ratio and before a small quantity of the graphite is recombusted to $\mathrm{CO}_{2}$ for conventional mass spectrometric determination of $\delta^{13} \mathrm{C}$; thus, fractionation caused by incomplete graphitization (Rayleigh fractionation) is compensated for in our correction based on the stable isotope ratio. Because all of our targets are prepared by compression of graphite to nearly identical pressures into identical target holders, which are sequentially rotated into identical positions in the Cs beam, we believe that there is no need to make a correction for "sputter fractionation"; our measurements of the corrected TAMS results on pairs of standards measured in the same wheels of targets indicate no larger uncertainty than the statistical uncertainty (Jull et $a l, 1986)$. If there are 2 standards in the wheel, for each circuit of the wheel a weighted average of the 2 corrected standard values is calculated and divided into the measured ${ }^{14} \mathrm{C} /{ }^{13} \mathrm{C}$ ratio of the sample during that circuit of the wheel. Individual values of $\left({ }^{14} \mathrm{C} /{ }^{13} \mathrm{C}\right)_{\text {sample }} /\left({ }^{14} \mathrm{C} /{ }^{13} \mathrm{C}\right)_{\text {standard }}$ are calculated for each of the usual 4 circuits of the whecl. This method prevents errors arising from undetected drifts of the tuning of the machine during the ca 12 hours that it takes to measure a wheel of 10 targets. An average of these 4 sample/standard ratios is calculated along with the standard deviation of the mean (scatter error). This uncertainty is compared to that calculated 
using the total numbers of ${ }^{14} \mathrm{C}$ events for the standard(s) and the sample (statistical crror). The larger of these 2 errors is selected, and to it is added the additional uncertainty in the blank correction factor. The fraction modern of the sample is calculated by taking the sample/standard value calculated above and making sample blank and stable isotope corrections on it. The ${ }^{14} \mathrm{C}$ age is then calculated in the usual manner as $-8033 \mathrm{yr}$ times $\mathrm{ln}$ (fraction modern carbon). The total uncertainty, calculated as a percentage, is multiplied by $8033 \mathrm{yr}$ to give the uncertainty of the age.

Our correction for the ${ }^{13} \mathrm{C} /{ }^{12} \mathrm{C}$ ratio of the sample or standard is made differently from conventional decay counting labs, where the raw quantity measured is the ${ }^{14} \mathrm{C} /{ }^{12} \mathrm{C}$ ratio. In correcting the ${ }^{14} \mathrm{C} /{ }^{13} \mathrm{C}$ ratio, we use the multiplicative factor $1-\left(\left(\delta^{13} \mathrm{C}+25\right) / 1000\right)$, ie, a factor of two is missing from the numerator in parentheses, relative to the factor used by decaycounting labs. We expect ultimately to be able to measure the ${ }^{13} \mathrm{C} /{ }^{12} \mathrm{C}$ ratios on the TAMS itself, but presently our precision is only ca $5 \%$.

We have attempted to determine the proper method of making a correction for the background or blank value of a sample. The "machine background" has been found to be virtually nil by measuring an Al blank target. We have determined that nearly all of the apparent background arises from the small amount of contemporary (1985 at this time) carbon which contaminates the sample during its chemical treatment and $\mathrm{Fe}-\mathrm{C}$ or graphite preparation (see Jull et al, 1986). For Fe-C, the average degree of sample contamination was ca $2.0 \pm 1.0 \%$ contemporary carbon originally, with this figure dropping ultimately to $1.0 \pm 0.5 \%$ contemporary $\mathrm{C}$ with improvements in sample processing techniques. For graphite, the average figure is still somewhat lower, ie, ca $0.50 \pm 0.15 \%$ contemporary, leading to a limit to our dating ability at this time to ca 46,000 year maximum. The blank value to be applied to each sample depends slightly on the amount of $\mathrm{CO}_{2}$ graphitized. The uncertainties of the percent contemporary (contamination) values given above include the uncertainty associated with varying sample size, because the graphite blanks were prepared from different volumes of dead $\mathrm{CO}_{2}$. However, starting in early spring 1985 , we have used a narrow range of $\mathrm{CO}_{2}$ volumes ( 1 to $4 \mathrm{mg} \mathrm{C}$ ), thus reducing the variability of the blank correction. Figure 2 plots the blank correction factor as a function of the measured value of the fraction modern. The value of the contemporary ${ }^{14}$ C level used is $119 \%$ "modern," based on extrapolation of the data of Nydal and Lövseth (1983) and Levin et al (1985); the blank value for graphite is the one used. (On this same plot is the percent error in the blank correction factor as a function of measured fraction modern (dashed line).

\section{RESULTS OF SELECTED MEASUREMENTS}

\section{Oxalic Acid Ratios}

Jull et al (1986) showed results of our graphite measurements of oxalic acid-II/AD 1890 wood ratios made in late 1984 and early 1985. Table 1 shows results of graphite measurements made in April and May 1985 of the oxalic acid-II/oxalic acid-I ratio, in terms of fraction modern of the oxalic acid-II. Again, the weighted average calculated agrees very well with the 


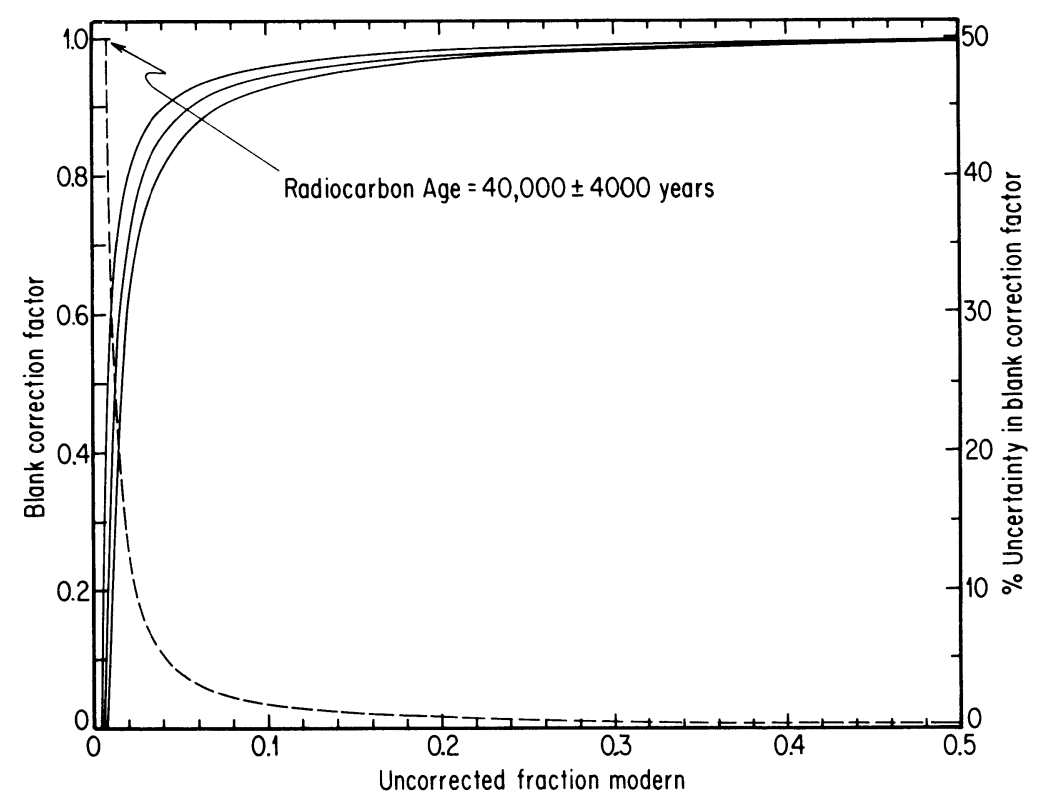

Fig 2. Blank correction factor as a function of measured fraction modern carbon. Basis of curves is average blank level of graphite samples prepared (Jull et al, 1986), ie, contamination with $0.50 \pm 0.15 \%$ contemporary (1985) atmospheric carbon. Solid curves show central line corresponding to the average value of the factor, with curves to either side showing 1 SD range. Dashed line is percent uncertainty in correction factor as a function of measured fraction modern carbon, one component of the total error of analysis.

correct value of this ratio (Mann, 1983; Stuiver, 1983). Also, to a level of $4 \%$, the precision, based only on the total number of ${ }^{14} \mathrm{C}$ counts accumulated, is in good agreement with the standard deviation of the weighted mean of these data.

\section{Variety of Projects}

During the past three years, we have performed ${ }^{14} \mathrm{C}$ analyses on a wide variety of sample materials for many researchers. Table 2 lists the types of projects on which we have collaborated in 1984. Other research performed at this facility is presented here (eg, Klouda et al, 1986; Long et al, 1985a, b; Stafford $e t$ al, ms; Tucker et al, ms). Other results are discussed below.

\section{Arizona Archaeologic Project}

T K Henderson, Arizona State University, undertook an extensive study of a site occupied by the Hohokam Indians ca $1000 \mathrm{yr}$ BP. A controversy had existed concerning the time of occupation of this site, which is now in downtown Phoenix. There were apparently two phases of the occupation of the site, the earlier known as the Snaketown phase, allegedly dating either from AD 300 to 500 by E Haury and H S Gladwin (T K Henderson, pers commun) or from AD 750 to 800 (Schiffer, 1982); the later phase, known as the Gila Butte phase, allegedly dated from either AD 500 to 700 or 
TABLE 1

Results of measurements of OX-II/OX-I ratio during April-May 1985

\begin{tabular}{|c|c|c|c|c|c|}
\hline Date & $\begin{array}{c}\text { Target numbers } \\
\text { OX-II/OX-I }\end{array}$ & $\begin{array}{l}\text { Sample/Std. } \\
\text { Ratios }\end{array}$ & 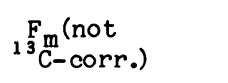 & $\begin{array}{l}{ }^{13} \mathrm{C} /{ }^{12} \mathrm{C} \\
\text { factor }\end{array}$ & $\begin{array}{l}\mathrm{F}_{\mathrm{m}}\left({ }^{13} \mathrm{C}-\right. \\
\text { corr. })\end{array}$ \\
\hline $03 \mathrm{Apr}$ & $1954 / 1994$ & 1.282 & $1.341 \pm 0.014$ & 0.9967 & 1.337 \\
\hline 04 Apr & $1954 / 1994$ & 1.290 & $1.349 \pm 0.015$ & 0.9967 & 1.345 \\
\hline $10 \mathrm{Apr}$ & $1954 / 1994$ & 1.288 & $1.347 \pm 0.015$ & 0.9967 & 1.343 \\
\hline $11 \mathrm{Apr}$ & $1954 / 1994$ & 1.310 & $1.370 \pm 0.016$ & 0.9967 & 1.365 \\
\hline 23 Apr & $1907 / 1994$ & 1.282 & $1.341 \pm 0.016$ & 1.0006 & 1.342 \\
\hline 24 Apr & $1907 / 1994$ & 1.286 & $1.345 \pm 0.017$ & 1.0006 & 1.346 \\
\hline 25 Apr & $2033 / 2032$ & 1.341 & $1.403 \pm 0.028$ & 0.9967 & 1.398 \\
\hline 30 Apr & $2033 / 2059$ & 1.298 & $1.358 \pm 0.024$ & 0.9967 & 1.353 \\
\hline 02 May & $2033 / 2032$ & 1.287 & $1.346 \pm 0.014$ & 0.9967 & 1.342 \\
\hline 03 May & $2076 / 2032$ & 1.335 & $1.397 \pm 0.019$ & 0.9934 & 1.388 \\
\hline 06 May & $2076 / 2081$ & 1.290 & $1.349 \pm 0.015$ & $(1.0000)$ & $(1.349)$ \\
\hline
\end{tabular}

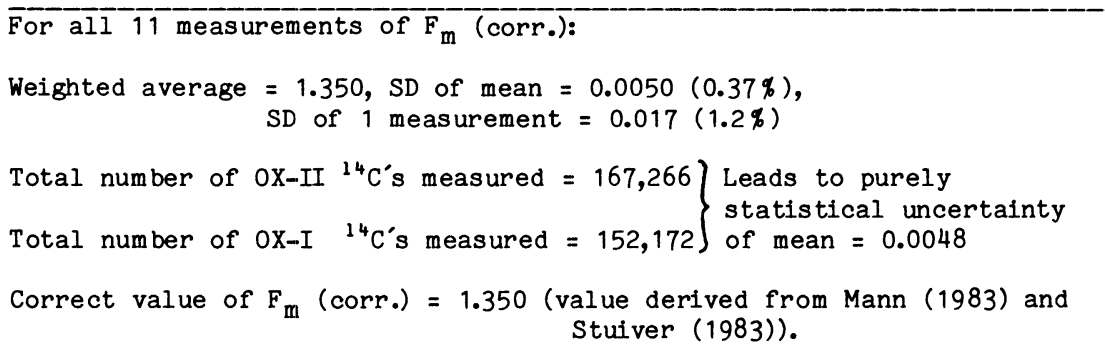

from AD 800 to 875 by the same people, respectively. In order to resolve this controversy, a suite of samples from late-Snaketown-phase pithouses from the village of La Ciudad was obtained for ${ }^{14} \mathrm{C}$ dating. Samples were carefully selected for annual plants or twigs from the time of occupation of the site. Because of the small size of these samples, the AMS method was selected. The results of these analyses, which happen to have come from the first all-graphite sets of Arizona samples measured are given in Table 3. Each "Feature" is a different pithouse. Those samples which gave ages $<900 \mathrm{BP}$ were assumed to be intrusive, with the exception of that from Feature 1308, which was known to have come from a later time. It was dated at $860 \pm 70 \mathrm{BP}$, which calibrates to AD 1040 to 1270 (Stuiver, 1982), agreeing with the estimated range of $\mathrm{AD} 1000$ to 1100 based on ceramics. The mean of the 11 results with ${ }^{14} \mathrm{C}$ ages $>900 \mathrm{yr} \mathrm{BP}$ is $1140 \mathrm{BP}$, with a standard deviation of $140 \mathrm{yr}$ and a standard deviation of the mean of $40 \mathrm{yr}$, though the 
TABLE 2

Arizona TAMS projects during 1984

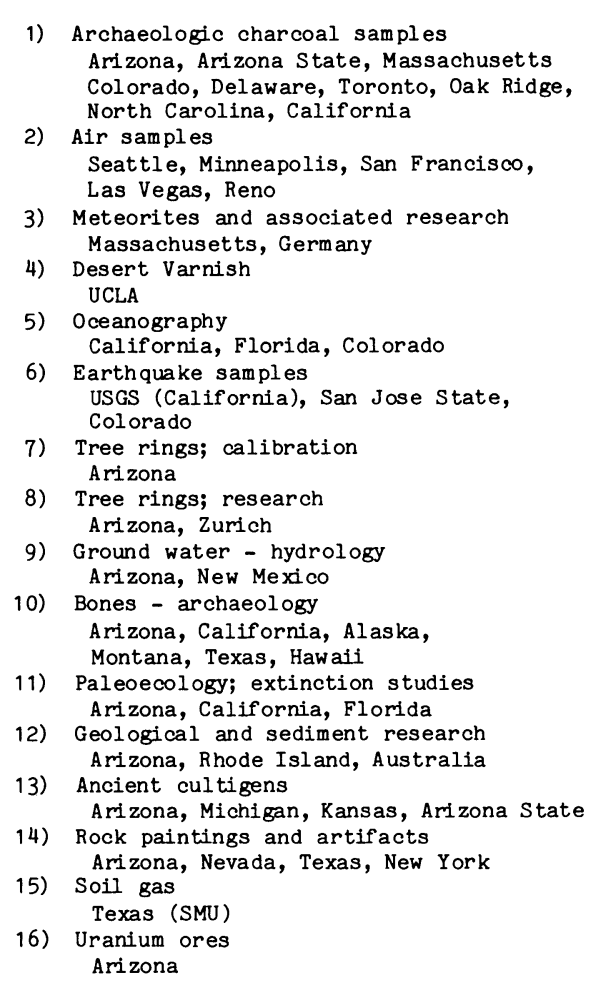

purely statistical error of the last quantity is $24 \mathrm{yr}$. The calibration of this mean, using $1 \sigma$, leads to a date range of AD 680 to 1020 for the 140 -yr SD and to a range of AD 780 to 980 based on the 40 -yr uncertainty. Thus, if the material came from the late Snaketown phase, the estimate of Schiffer, which is the later of the two estimates, is clearly the correct one.

\section{Faunal Paleoextinctions}

The dates of extinctions of megafauna have been studied extensively by P S Martin, University of Arizona, and J I Mead, University of Maine, among others. When deposited in a protected, dry environment, such as some caves in the American southwest, mammalian material may remain very well preserved for thousands of years, whereas the material would be degraded in a matter of months or years in an unprotected environment. At one time, two completely different species of mammal, Harrington's mountain goat (Oreamnos harringtoni) and the Shasta ground sloth (Nothrotheriops shastensis) occupied the same region; both species are now extinct. Although both were large herbivores, their anatomical structures, diets, 
TABLE 3

Dating of material from Hohokam Indian site in Arizona

\begin{tabular}{|c|c|c|c|c|}
\hline Feature no. & Henderson no. & TAMS no. & ${ }^{14} \mathrm{C}$ age & $\mathrm{BP}$ \\
\hline \multirow[t]{3}{*}{882} & $44061 \mathrm{~A}$ & AA -964 & $1160 \pm$ & 80 \\
\hline & 44093 & $A A-965$ & $980 \pm$ & 80 \\
\hline & 37905 & $A A-968$ & $1390 \pm 1$ & 100 \\
\hline 1411 & $48097 \mathrm{~A}$ & $A A-957$ & $960 \pm$ & 80 \\
\hline \multirow[t]{2}{*}{887} & 37823 & $A A-960$ & $1260 \pm$ & 70 \\
\hline & 44483 & AA -966 & $1020 \pm$ & 80 \\
\hline \multirow[t]{3}{*}{512} & $48684 \mathrm{~A}$ & AA -956 & $650 \pm$ & 60 \\
\hline & $48684 \mathrm{~B}$ & AA -962 & $1120 \pm$ & 80 \\
\hline & 44328 & AA -961 & $1250 \pm$ & 70 \\
\hline \multirow[t]{3}{*}{1751} & 50237 & $A A-959$ & $1260 \pm$ & 90 \\
\hline & 50200 & $A A-963$ & $990 \pm$ & 80 \\
\hline & 50203 & $A A-967$ & $1180 \pm$ & 80 \\
\hline 1780 & 38730 & $A A-955$ & $780 \pm$ & 70 \\
\hline 1308 & 35289 & $A A-958$ & $860 \pm$ & 70 \\
\hline
\end{tabular}

social behavior, locomotion, mobilities, and regions of origin were sufficiently different to deem it unlikely that a natural stress, such as climatic change, would cause the near-simultaneous extinction of both, a conclusion made by Mead et al (1986) based on ${ }^{14} \mathrm{C}$ dating of preserved remains of both species. Among the well-preserved materials coming from the extinct mountain goat are keratinous horn sheaths, fecal pellets, and soft tissue; these have been found in a few dry caves in the Grand Canyon of Arizona. While dung samples that have been found have sometimes been large enough for conventional dating, the samples of the horn sheaths are too precious for much material to be sacrificed for conventional ${ }^{14} \mathrm{C}$ dating. We have dated many samples of horn sheath by AMS while dung samples have been measured at the Arizona conventional facility. The results of these analyses for samples from two caves are presented in Table 4 which shows that Harrington's mountain goat existed in Rampart Cave from ca 29,000 ${ }^{14} \mathrm{C}$ yr BP until its apparent extinction at ca 10,000 yr BP. In Stanton's Cave, evidence of this species was found from ca 23,000 yr BP until ca 11,000 yr BP. The apparent extinction of the Shasta ground sloth was also at ca $11,00()$ yr BP (Long \& Martin, 1974). According to Martin, Thompson and Long (1986), the lowest ${ }^{14} \mathrm{C}$ ages ever measured for Shasta ground sloths 
TABI.E 4

Dates on Harrington's mountain goat samples from the Grand Canyon, Arizona

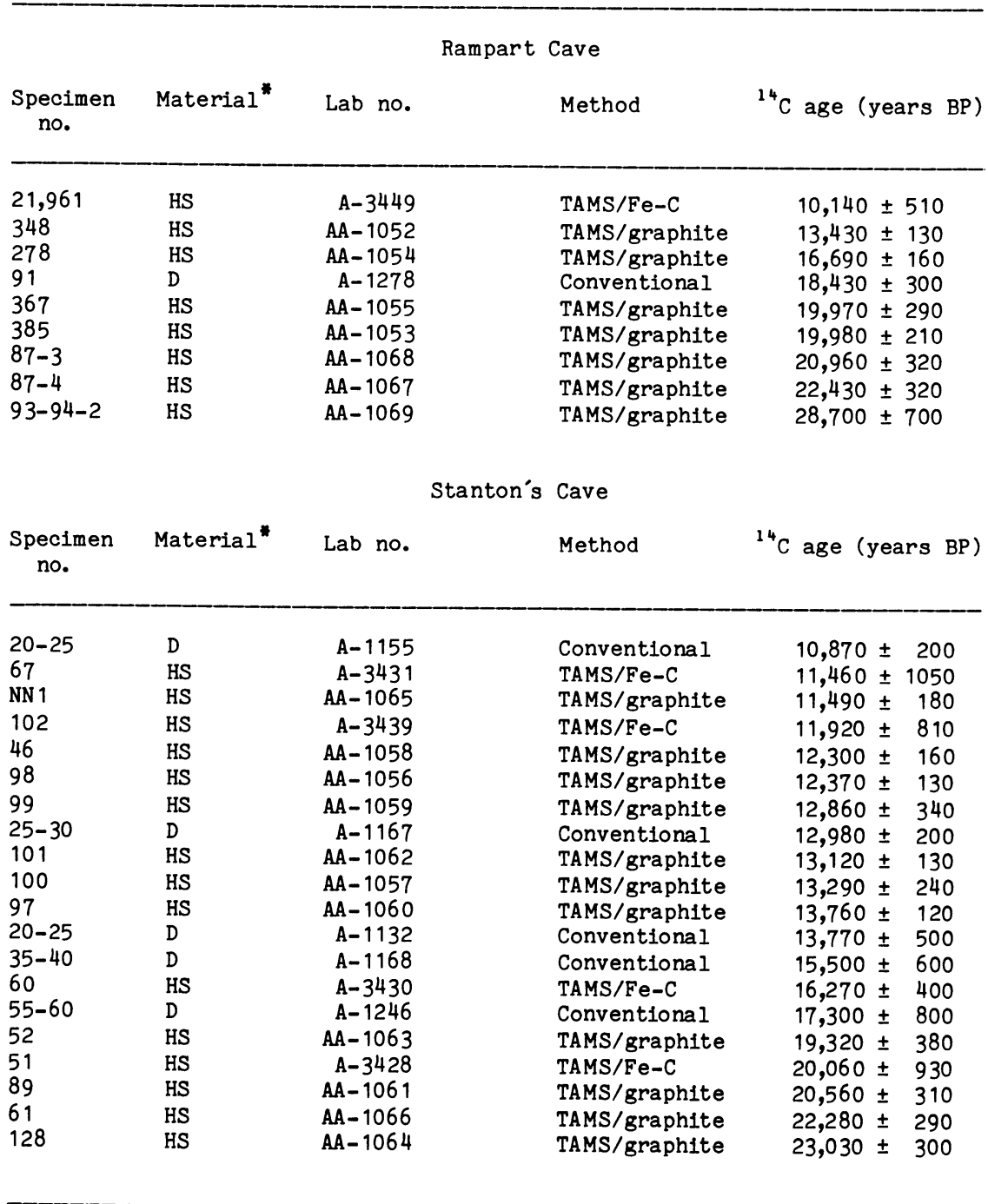

Material: HS = horn sheath $D=$ dung pellets

and, now, Harrington's mountain goats of Arizona, Nevada, west Texas, and New Mexico are about the same as the lowest ages found for machairodont cat, horse, and bison in southern California. It is a controversial matter as to whether this near-simultaneous extinction at ca $11,000 \mathrm{yr}$ BP of several very different megafauna is just a coincidence, whether it is climate related (though this does not appear to be the case), or whether a third hypothesis favored by P S Martin is the case; his belief is that Clovis big game hunters actively reduced these species by predation below the num- 
ber needed to maintain their existence (Martin, 1984); it is also possible that important changes in the flora were happening at the same time.

\section{Growth of Phosphorites on the Ocean Floor}

W C Burnett, Florida State University, has been studying the growth of phosphorite nodules on the continential shelf off the coast of Peru (Burnett, Beers \& Roe, 1982). These nodules grow downward into the soft sediment, obtaining their phosphorus from upward diffusion through sediment pore water. Four slices were made of one such phosphorite nodule, sample no. PD 15-17, to find its growth rate. These samples were first dated by ${ }^{230} \mathrm{Th}$ dating (using ${ }^{230} \mathrm{Th} /{ }^{234} \mathrm{U}$ activity ratios). Samples were later submitted to us for ${ }^{4} \mathrm{C}$ dating using the TAMS. The calcite carbon was removed from these by treatment with acetic acid. To obtain the carbon from the primary constituent of these nodules, carbonate fluorapatite (CARFAP):

$$
(\mathrm{Ca}, \mathrm{Na}, \mathrm{Mg}, \mathrm{Sr})_{10}\left(\mathrm{PO}_{4}, \mathrm{CO}_{3}, \mathrm{SO}_{4}\right)_{6} \mathrm{~F}_{2-3} \text {, }
$$

the sample was then reacted with phosphoric acid to release the apatite carbon which was then dated on the TAMS. Results of both the U-series and the ${ }^{14} \mathrm{C}$ dating are shown in Figure 3 . The ${ }^{230} \mathrm{Th}$ ages have to be corrected for the non-radiogenic fraction of that isotope present, leading to the two

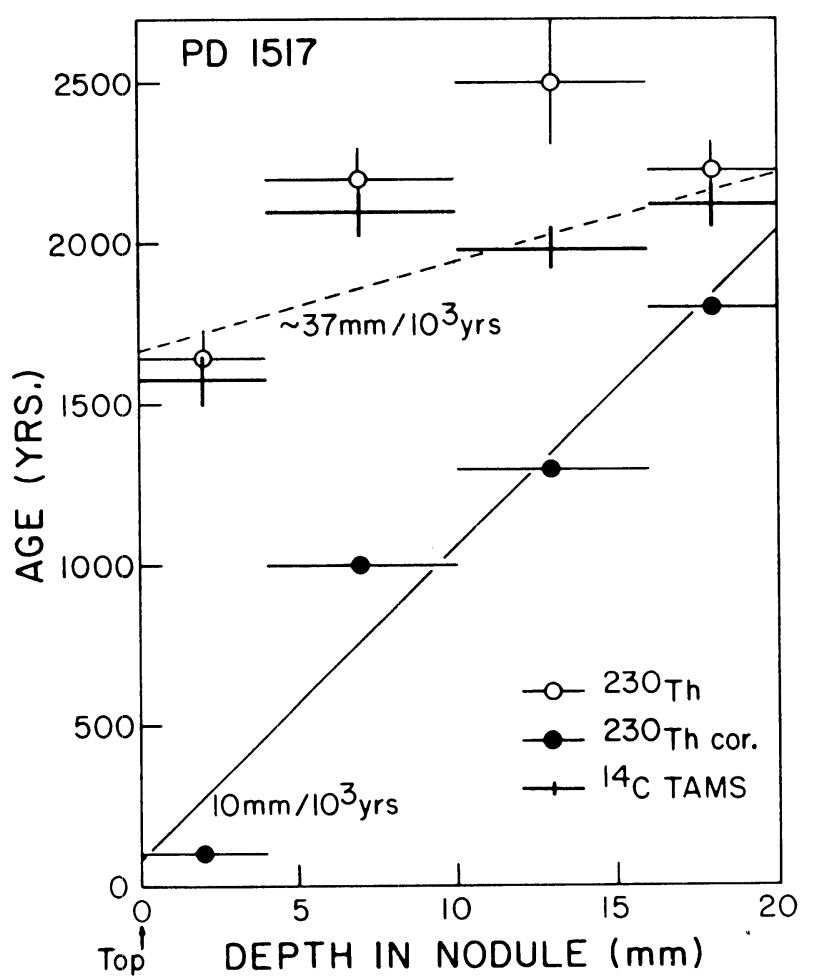

Fig 3. Age $v$ s depth in phosphorite nodule PI) 1517. -O- = uncorrected ${ }^{230}$ Th ages; $-9=$ ${ }^{230} \mathrm{Th}$ ages corrected for nonradiogenic ${ }^{230} \mathrm{Th} ;+={ }^{14} \mathrm{C}$ ages measured at the Arizona TAMS. 
sets of $\mathrm{U}$-series data (uncorrected and corrected) plotted. The ${ }^{14} \mathrm{C}$ ages are in between those sets. This is as might be expected, because the source of the carbon is the oceanic bicarbonate in this area of upwelling of deeper, ${ }^{14} \mathrm{C}$-depleted water. Thus, the true ages of the samples are likely to be somewhat younger than the ${ }^{14} \mathrm{C}$ ages, as shown. In any case, the growth rate of the nodule appears to be $37 \pm 10 \mathrm{~mm} / 1000 \mathrm{yr}$. This creates an interesting situation, because the sedimentation rate there is ca $1 \mathrm{~mm} /$ year, in which case this nodule should have been under $2 \mathrm{~m}$ of sediment.

We have also studied the growth of phosphatic crust obtained from a box core, with sediment above and below it; both $\mathrm{U}$-series and TAMS ${ }^{14} \mathrm{C}$ dating of this crust showed that it grew in an upward direction and that the growth rate was ca $10 \mathrm{~mm} / 1000 \mathrm{yr}$.

Burnett has also measured the ${ }^{14} \mathrm{C}$ in sedimentary organic carbon, and we have measured the ${ }^{14} \mathrm{C}$ in CARFAP of small phosphate pellets found in the same layers. The results of this work show that the pellets actually formed within those sediment layers and were not old, re-worked material that washed into the area.

\section{ACKNOWLEDGMENTS}

We thank A Hatheway for his assistance in all phases of this work. This work was funded by NSF grant EAR-83-()9448.

\section{REFERENCES}

Burnett, W C, Beers, M J and Roe, K K, 1982, Growth rates of phosphate nodules from the continental margin off Peru: Science, v 215, p 1616-1618.

Donahue, D J, Zabel, T H, Jull, A J T and Damon, P E, 1983, Results of tests and measurements from the NSF Regional Accelerator Facility for Radioisotope Dating, in Stuiver, $M$ and Kra, R S, eds, Internatl ${ }^{14} \mathrm{C}$ conf, $11 \mathrm{th}$, Proc: Radiocarbon, v 25, no. 2, p $719-728$.

Donahue, I) J, Jull, A J T and Zabel, T H, 1984, Results of radioisotope measurements at the NSF-University of Arizona tandem accelerator mass spectrometer facility: Nuclear Instruments \& Methods, v B5, p 162-166.

Jull, A J T, Donahue, D J, Hatheway, A, Linick, T W and Toolin, I, J, 1985, Production of graphite targets by deposition from $\mathrm{CO} / \mathrm{H}_{2}$ for precision accelerator ${ }^{14} \mathrm{C}$ measurements, in Stuiver, $\mathrm{M}$ and Kra, R S, eds, Internatl ${ }^{14} \mathrm{C}$ conf, 12 th, Proc: Radiocarbon, this issue.

Klouda, ( A A, Currie, L. A, Donahue, I) J and Jull, A J T, 1986, Urban atmospheric ${ }^{14} \mathrm{CO}$ and ${ }^{14} \mathrm{CH}_{4}$ measurements by accelerator mass spectrometry, in Stuiver, $\mathrm{M}$ and Kra, R S, eds, Internatl ${ }^{14} \mathrm{C}$ conf, 12 th, Proc: Radiocarbon, this issue.

Lcvin, I, Kromer, B, Schoch-Fischer, H, Bruns, M, Münnich, M, Dietrich, B, Vogel, J C and Münnich, $\mathrm{K}\left(\mathrm{)}, 1985,25\right.$ years of tropospheric ${ }^{14} \mathrm{C}$ observations in central Europe: Radiocarbon, v 27, no. 1, p $1-19$.

I.ong, A, Donahue, I) J, Jull, A J T, and I inick, T W (ms), $1985 \mathrm{a}$, Tandem accelerator dating of archaeological cultigens: Paper presented at Internatl ${ }^{14} \mathrm{C}$ conf, 12 th, Trondheim, Norway, June $24-28$.

Long, A and Martin, P S, 1974, Death of American ground sloths: Science, v 186, p 638640 .

Long, A, Murphy, E, Thurman, E M, Davis, S N, Malcolm, R L, Donahue, D J, Jull, A J T and Linick, T W (ms), $1985 \mathrm{~b}$, Tandem accelerator ${ }^{14} \mathrm{C}$ analyses on dissolved organic matter in ground water: Paper presented at Internatl ${ }^{14} \mathrm{C}$ conf, 12 th, Trondheim, Norway, June 24-28.

Mann, W B, 1983, An international reference material for radiocarbon dating, in Stuiver, $\mathrm{M}$ and Kra, R S, eds, Internatl ${ }^{14} \mathrm{C}$ conf, $11 \mathrm{th}$, Proc: Radiocarbon, v 25, no. 2, p 519-528.

Martin, P S, 1984, Prehistoric overkill: the global model, in Martin, P S, and Klein, R G, eds, Quaternary extinctions-a prehistoric revolution: Tucson, Univ Arizona Press, p $345-$ 403.

Martin, P S, Thompson, R S, and Long, A, 1986, in Mead, J I and Meltzer, D J, eds, Environments and extinctions: man in late glacial North America: Univ Maine, Center for the Study of Early Man, Orono, Maine, in press.

Mead, J I, Martin, P S, Euler, R C, Long, A, Jull, A J T, Toolin, L. J, Donahue, D J and Linick, 
T W, 1986, Extinction of Harrington's mountain goat, in Natl Acad Science USA, Proc: $\mathrm{v}$ 83, p $836-839$

Nydal, R and Lövseth, K, 1983, Tracing bomb ${ }^{14} \mathrm{C}$ in the atmosphere 1962-1980: Jour Geophys Research, v 88, no. C6, p $3621-3642$.

Schiffer M B 1982. Hohokam chronology: an essay on history and method, in McGuire, R M and Schiffer, M B, eds, Hohokam and Patayan, prehistory of southwestern Arizona: New York, Academic Press.

Stafford, T W, Jr, Jull, A J T, Donahue, D) J, Brendel, K, and Duhamel, R (ms), 1985, Studies on the radiocarbon dating of fossil bones by accelerator mass spectrometry and the stable carbon and nitrogen isotopic composition of dated organic fractions: Paper presented at Internatl ${ }^{14} \mathrm{C}$ conf, 12 th, Trondheim, Norway, June $24-28$

Stuiver, M, 1982, A high-precision calibration of the AD radiocarbon time scale: Radiocarbon, $v 24$, no. 1, p $1-26$.

_ 1983, International agreements and the use of the new oxalic acid standard, in Stuiver, $\mathrm{M}$ and Kra, R S, eds, Internatl ${ }^{14} \mathrm{C}$ conf, 11 th, Proc: Radiocarbon, v 25, no. 2, $\mathrm{P}$ $793-795$.

Tucker, A B, Tinsley, J C, Atwater, B F, Trumm, D A, Robinson, S W, Stein, R E, Donahue, DJ and Jull, A J T (ms), 1985, Accelcrator dating of detrital and burned-in-place charcoal from the alluvium of Los Gatos Creek: Paper presented at Internatl ${ }^{14} \mathrm{C}$ conf, 12th, Trondhcim, Norway, June 24-28. 